\title{
Detecting Land-Cover Change using Mappable Vegetation Related Indices: A Case Study from the Sinharaja Man and Biosphere Reserve
}

\author{
B.D. Madurapperuma ${ }^{1^{*}}$ and K.A.J.M. Kuruppuarachchi ${ }^{2}$ \\ ${ }^{I}$ Department of Forestry and Natural Resources, Purdue University, West Lafayette, IN 47906, USA \\ ${ }^{2}$ Department of Botany, The Open University of Sri Lanka, Nawala, Nugegoda, Sri Lanka
}

Date Received: 04-10-2013 Date Accepted: 05-04-2014

\begin{abstract}
Understanding the effects of human disturbances at the forest fringe is useful in efforts to implement best management practices aimed at conserving forest resources. This study evaluates multi-year changes of vegetation in the Sinharaja Man and the Biosphere (MAB) reserve using mappable vegetation related indices viz., Normalized Difference Vegetation Index (NDVI) and Burn Index (BI). Land-cover changes in the Sinharaja MAB reserve were detected using Landsat $7 \mathrm{ETM}^{+}$images for 1993, 2001, and 2005, and DIVA GIS land-cover data in 2000. NDVI resulted in a 962 ha increase of vegetation prime at the western Sinharaja from 2001-2005 and a 15 ha decrease of vegetation at the southern Sinharaja from 1993-2005. Results from BI showed that the Sinharaja MAB reserve fringe is vulnerable to forest fire. This vulnerability can be seen in the following totals of burned hectares: 160 ha from 1993-2001, 79 ha from 2001-2005, and 10 ha for the entire period of 1993-2005. According to the land-cover map, burn area occurred at the cultivated lands, scrublands, and fragmented forest fringe. The results were visualized using an embedded 3D render window of Google Earth and a 2D view of ArcGIS explorer online. In conclusion, insitu ground truthing data is needed for the fire-influenced area for implementing sustainable forest resource management at the Sinharaja MAB reserve.
\end{abstract}

Keywords: Burn index, Google Earth, Mapping, NDVI, Sinharaja MAB reserve

\section{Introduction}

The southwestern region in Sri Lanka is a showcase for biodiversity, where lowland rainforests harbour high endemic and threaten taxa (Gunatilleke \& Gunatilleke, 1991). For example, the Sinharaja rainforest, the largest primary rainforest in Sri Lanka, contributed over 60\% endemic flora (Gunatilleke \& Gunatilleke, 1996; Gunatilleke et al., 2005) and 23\% endemic vertebrate fauna (de Zoysa \& Raheem, 1990). Even though the Sinharaja forest reserve contributes a mere $13 \%$ of the protected forests in the wet zone, despite its biological wealth, it was declared a national heritage wilderness area in 1988 (NCR, 1997). Prior to being declare a protected forest natural resources were extracted at an alarming rate. The Sinharaja forest reserve has been primarily disturbed through logging for supplying timber for the plywood industry between 1972 and 1977 (Sri Bharathie, 1979; NCR, 1997). In 1977, logging operations were ceased and the degraded area was included in the forest reserve.

\footnotetext{
*Correspondence: bmadurap@purdue.edu Tel: +17654094382

ISSN 2235-9370 Print/ISSN 2235-9362 Online @ University of Sri Jayewardenepura
} 
Human induced disturbances such as, shifting cultivation, extraction of non-timber forest products, and human encroachment were found at the forest fringe of Sinharaja (de Zoysa et al., 1989; McDermott et al., 1990; Gunatilleke, 1998). The rural communities, who live proximity to the Sinharaja forest depend on the forest resources to meet their subsistence and income needs (Gunatilleke et al., 1993; Kathriarachchi et al., 2004). Therefore, creating wildness areas at the human-forest interface is useful not only for protecting forest resources from disturbances, but also beneficial for local communities. Collaboration with village communities is vital for implementing sustainable forest management programs in order to protect the government forest. The Sinharaja rainforest exists within a $3 \mathrm{~km}$ wide buffer zone, which reduces human encroachment especially from tea and rubber plantations (Gunatilleke \& Gunatilleke, 1985; Wijesooriya \& Gunatilleke, 2003).

Understanding landscape patterns and processes, which are influenced by human activities and/or natural phenomenon is essential for proper land management and policymaking (Prakasam, 2010). However, there are major gaps in knowledge on how spatially constrained forest cover change over time. This knowledge is useful to understand the significance of habitat fragmentation, which causes edge effects resulting in biodiversity loss.

This study assesses the changes of vegetation in Sinharaja that were caused by selective logging and slash and burn cultivation (Gunatilleke \& Gunatilleke, 1985). Therefore, it is important to assess post-disturbance recovery of the Sinharaja forest in terms of spatial and temporal perspectives.

We hypothesized that the fire intensity at the Sinharaja buffer zone is high compared to the core region that contributes significant vegetation reduction at the forest fringe. The research questions addressed in this paper were:

(i) How the land-cover has changed in Sinharaja from 1993 to 2005

(ii) How the fire has impacted the forest reserve and the buffer zone over the 12 years

The answers for these questions will eventually provide insight for sustainable forest management and policy making for the conservation of the Sinharaja MAB reserve.

Study site

The Sinharaja MAB reserve is situated in the south-west lowland wet zone of Sri Lanka within the Sabaragamuwa and Southern provinces $\left(6^{\circ} 21^{\prime}-6^{\circ} 26^{\prime} \mathrm{N}, 80^{\circ} 21^{\prime}-80^{\circ} 34^{\prime} \mathrm{E}\right)$ that span over the administrative boundaries of Rathnapura, Galle and Matara (Fig. 1).

The total extent of 11,187 ha has been legally protected as a core region of Sinharaja MAB with a $3 \mathrm{~km}$ external buffer zone (Bandaratilleke, 1992; NCR, 1997). Sinharaja is a primary forest comprised of mixed dipterocarp and lower montane forest, which extends across an altitudinal range of 210 to $1,180 \mathrm{~m}$ (Gunatilleke et al., 1996). The mean annual rainfall in Sinharaja ranges from 3,600 to $5,000 \mathrm{~mm}$ and the temperature varies between $19^{0}$ and $27^{\circ} \mathrm{C}$. 


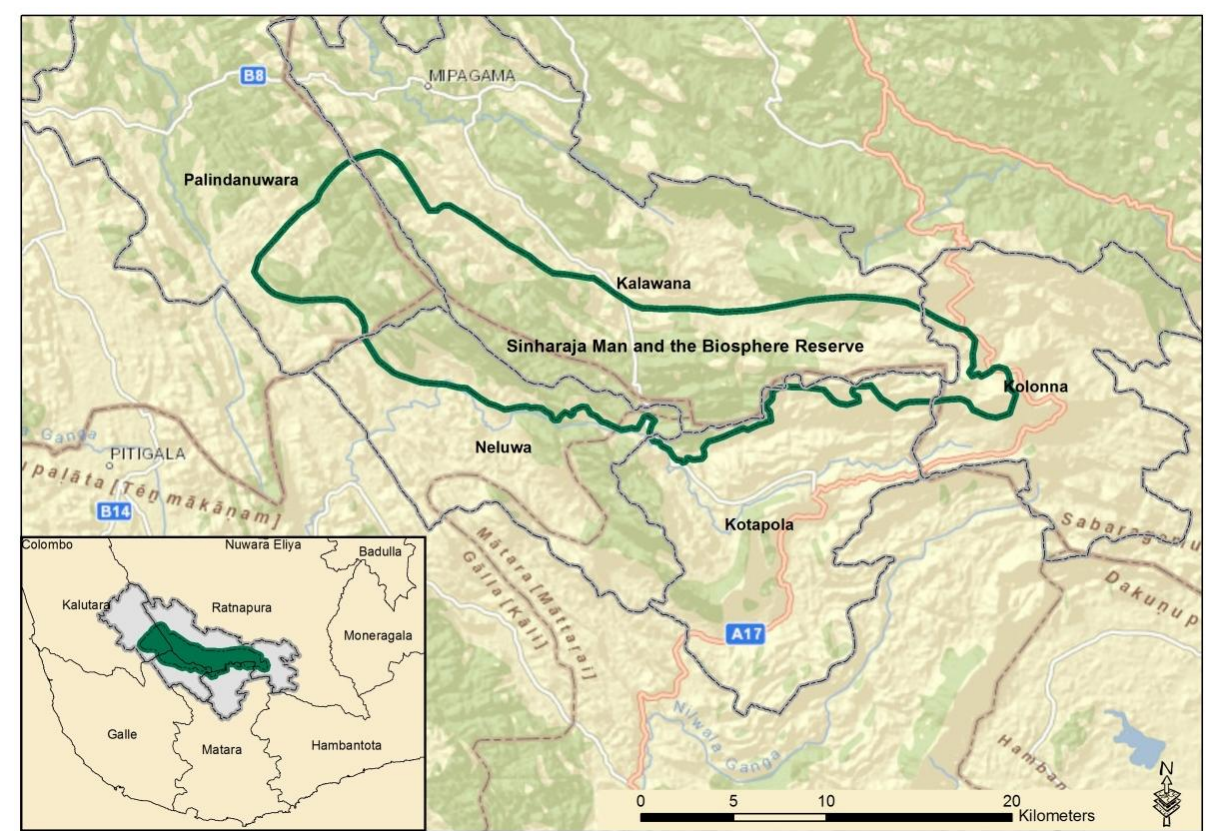

Fig. 1: Study area map showing the Sinharaja MAB reserve and administrative boundaries.

\section{Materials and Methods}

Landsat $7 \mathrm{ETM}^{+}$images of the study area were acquired from the Global Land Cover Facility web portal (http://glcf.umd.edu/data/landsat/). These images were acquired over the span of three different years viz., 1993, 2001 and 2005. The details of the acquired images, including the Worldwide Reference System (WRS), path, and row information are given by Table 1. The images are on a scale of $30 \mathrm{~m}$ spatial resolution. Seven individual bands of each image were converted to new multiband files by layer stacking using $\mathrm{ENVI}^{\circledR} 4.5$. Then the multiband files were re-projected to UTM Zone 44 North, WGS-84 Datum.

Table 1: Landsat time series scenes used in the study.

\begin{tabular}{ccccccc}
\hline Satellite & Date & Sensor & Resolution & WRS & Path & Row \\
\hline Landsat 7 & $12 / 02 / 1993$ & ETM+ & $30 \mathrm{~m}$ & 2 & 141 & 56 \\
Landsat 7 & $14 / 03 / 2001$ & ETM+ & $30 \mathrm{~m}$ & 2 & 141 & 56 \\
Landsat 7 & $05 / 02 / 2005$ & ETM+ & $30 \mathrm{~m}$ & 2 & 141 & 56 \\
\hline
\end{tabular}

Thereafter, each data set was exported to ENVI ${ }^{\circledR}$ EX environment and an image difference tool was used to detect the changes between the 1993 to 2005 time steps based on the Normalized Difference Vegetation Index (NDVI) and Normalized Difference Burn Index (NDBI). NDVI measures seasonal and inter-annual changes in vegetation growth and activity (Jensen, 2005). NDVI is functionally equivalent to simple band ratios of ETM images and can be described by the following equation (1):

$\operatorname{NDVI}=\left(\rho_{\text {nir }}-\rho_{\text {red }}\right) /\left(\rho_{\text {nir }}+\rho_{\text {red }}\right)$

where:

$$
\begin{aligned}
& \rho_{\text {nir }}=\text { spectral reflectance for band } 4 \\
& \rho_{\text {red }}=\text { spectral reflectance for band } 3
\end{aligned}
$$

NDBI measures burn severity in terms of simple band ratios of ETM bands 4 and 7 and is given by equation (2). Those bands exhibited the greatest reflectance change in response to fire (Key et al., 2002). 
$\mathrm{NDBI}=\left(\rho_{\text {band } 4}-\rho_{\text {band } 7}\right) /\left(\rho_{\text {band } 4}+\rho_{\text {band } 7}\right)$

where:

$$
\begin{aligned}
& \rho_{\text {band } 4}=\text { spectral reflectance for band } 4 \\
& \rho_{\text {band } 7}=\text { spectral reflectance for band } 7
\end{aligned}
$$

Each NDVI and NDBI data were imported to virtual globes such as Google Earth and ArcGIS online platforms to create change detection maps of the study area. Google Earth is a powerful mapping software, which can be used to visualize three-dimensional representations of terrain topography. Similarly, ArcGIS online platforms were used to visualize landscape changes over time with layers of road, rivers and administrative boundaries of the study area. The villages within the Sinharaja MAB reserve were obtained from the DIVA GIS web portal (http://www.diva-gis.org/Data) and $500 \mathrm{~m}$ buffer zones were created in each village. Then vegetation-changed results were compared within the $500 \mathrm{~m}$ buffer zones.

\section{Results}

This study assesses land-cover change in the Sinharaja MAB reserve over 12 years, spanning the periods of 1993-2001, 2001-2005 and 1993-2005, using mappable vegetation related indices, such as NDVI and NDBI. The vegetation growth showed a 962 ha increase of vegetation prime at the western Sinharaja in 2001-2005 (Fig. 2). In addition, a 15 ha area of vegetation decreased at the sourthern Sinharaja from 1993 to 2005.

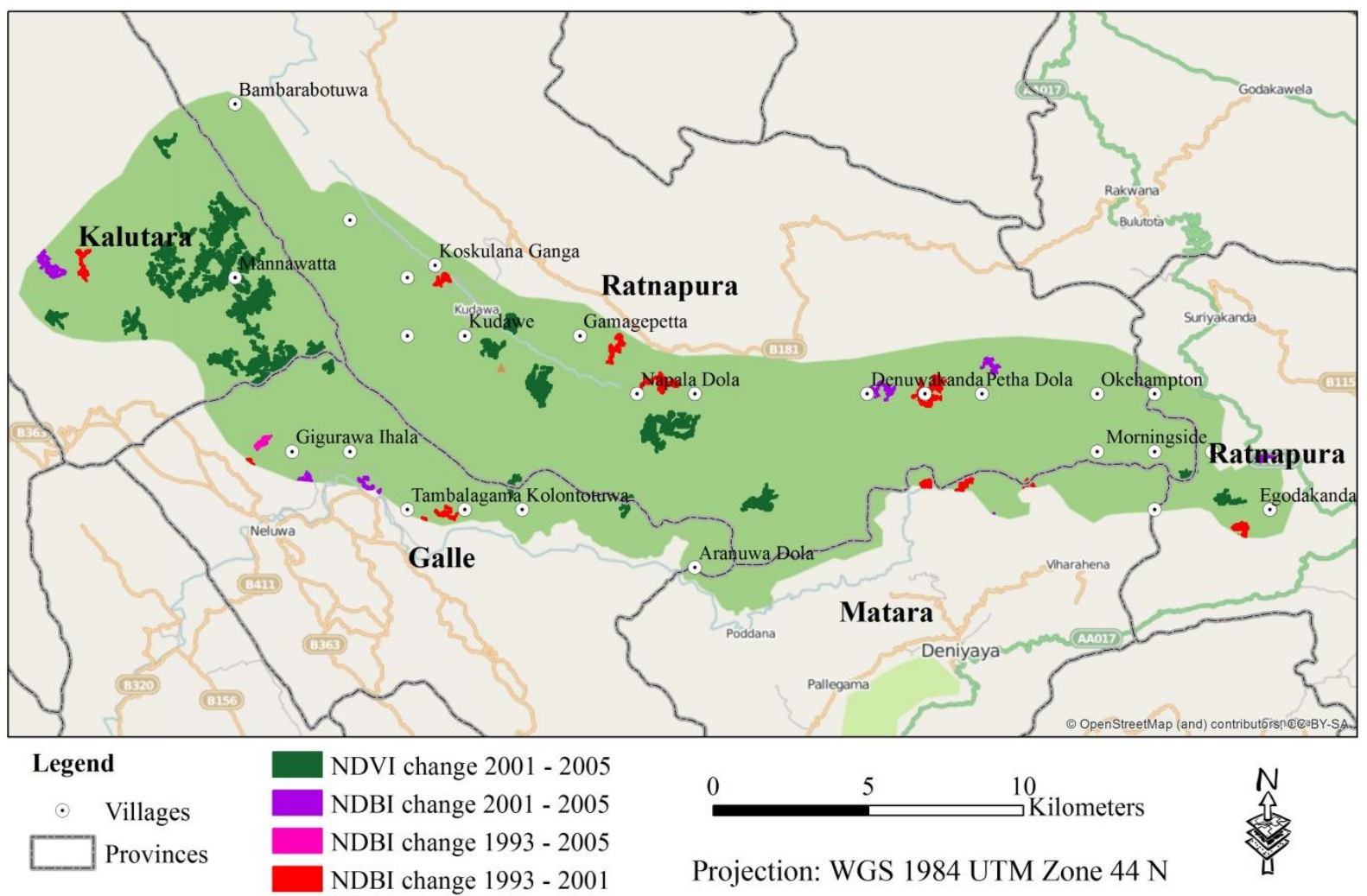

Fig. 2: Land-cover change detection using NDVI and NDBI indices in the Sinharaja forest reserve from 1993 to 2005. 
Results of the Burn Index showed that the Sinharaja MAB reserve fringe was vulnerable to forest fire compared to the co-region of the Sinharaja MAB reserve. For example, the 1993 image compared to the 2001 image revealed 160 ha burned. The 2001 image compared to the 2005 image showed 79 ha burnt. For the entire period, the 1993 image compared to 2005 image revealed 10 ha burnt.

The Sinharaja MAB reserve is governed by 41 villages, which are located inside a three-kilometer buffer within the reserve's boundary (Table 2, Fig. 2). These 41 villages represent three provinces viz., Sabaragamuwa, Southern and Western. The villagers represented four districts including: 32 villages from Rathnapura, 7 villages from Galle, 1 village each, Matara and Kalutara. Of the villages, Mannawatta (western Sinharaja) and Kolontotuwa (sourthern Sinharaja) showed a NDVI increased between 2001 and 2005. In contrast, Koskulana Ganga, Napala Dola, Kekillapitiya, Warukandeniya, Pelawatta and Tambalagama observed a NDBI decrease between 1993 and 2005.

Table 2: Villages in the Provinces of Sabaragamuwa (SA), Southern (SO) and Western (WE) and in the Districts of the Rathnapura (RA), Galle (GA), Matara (MA) and Kalutara (KA) in the Sinharaja forest reserve.

\begin{tabular}{llll}
\hline Village Name & $\begin{array}{l}\text { Division \& } \\
\text { District }\end{array}$ & Village Name & $\begin{array}{l}\text { Division \& } \\
\text { District }\end{array}$ \\
\hline Bambarabotuwa & SA, RA & Pelawatta & SA, RA \\
Calton Hill & SA, RA & Petha Dola & SA, RA \\
Denuwakanda & SA, RA & Pethiyakanda & SA, RA \\
Diyapotagam Pattuwa & SA, RA & Petiyakanda & SA, RA \\
Dolahena & SA, RA & Pitakele & SA, RA \\
Edandu Ela & SA, RA & Pitigalakanda & SA, RA \\
Egodakanda & SA, RA & Rawreth & SA, RA \\
Gamagepetta & SA, RA & Rew & SA, RA \\
Gongala & SA, RA & Sinna Caldone & SA, RA \\
Hapugoda & SA, RA & Tangamale Plains & SA, RA \\
Heen Dola & SA, RA & Wewagama & SA, RA \\
Ittekanda & SA, RA & Aranuwa Dola & SO, GA \\
Kekillapitiya & SA, RA & Gigurawa Ihala & SO, GA \\
Kongahakanda & SA, RA & Gigurawa Pahala & SO, GA \\
Koskulana Ganga & SA, RA & Kolontotuwa & SO, GA \\
Kudawe & SA, RA & Kosmulla & SO, GA \\
Kudawe Ganga & SA, RA & Tambalagama & SO, GA \\
Maha Ganga & SA, RA & Warukandeniya & SO, GA \\
Morningside & SA, RA & Abbey Rock & SO, MA \\
Napala Dola & SA, RA & Mannawatta & WE, KA \\
Okehampton & SA, RA & & \\
\hline
\end{tabular}

Source: Data was acquired from Diva GIS web portal gazetteer

The results of vegetation growth and the burned area are visualized using an embedded 3D render window of Google Earth (Fig. 3). The results showed that the periphery of the forest reserve is vulnerable to forest fire. Disturbances of fire on sites were clearly visible from Google Earth when maps zoomed into a particular area. The conspicuous 
vegetation growth in the forest reserve was observed in the Kalutara district in 2001-2005 (Figs. $2 \& 3$ ).

A land-use/cover map for the Sinharaja MAB reserve was created using Diva GIS data, which originary derived from Global land cover data in 2000 at $1 \mathrm{~km}$ spatial resolution (Fig. 4). Table 3 summarizes the extent of land-use/cover within the Sinharaja reserve boundary. Generally, co-areas of Sinharaja MAB reserve are comprised of evergreen forest and some periphery areas are converted to croplands or shrubland. For example, $93 \%$ of the area is evergreen forest, while $6 \%$ is comprised of cultivated and/or managed areas.

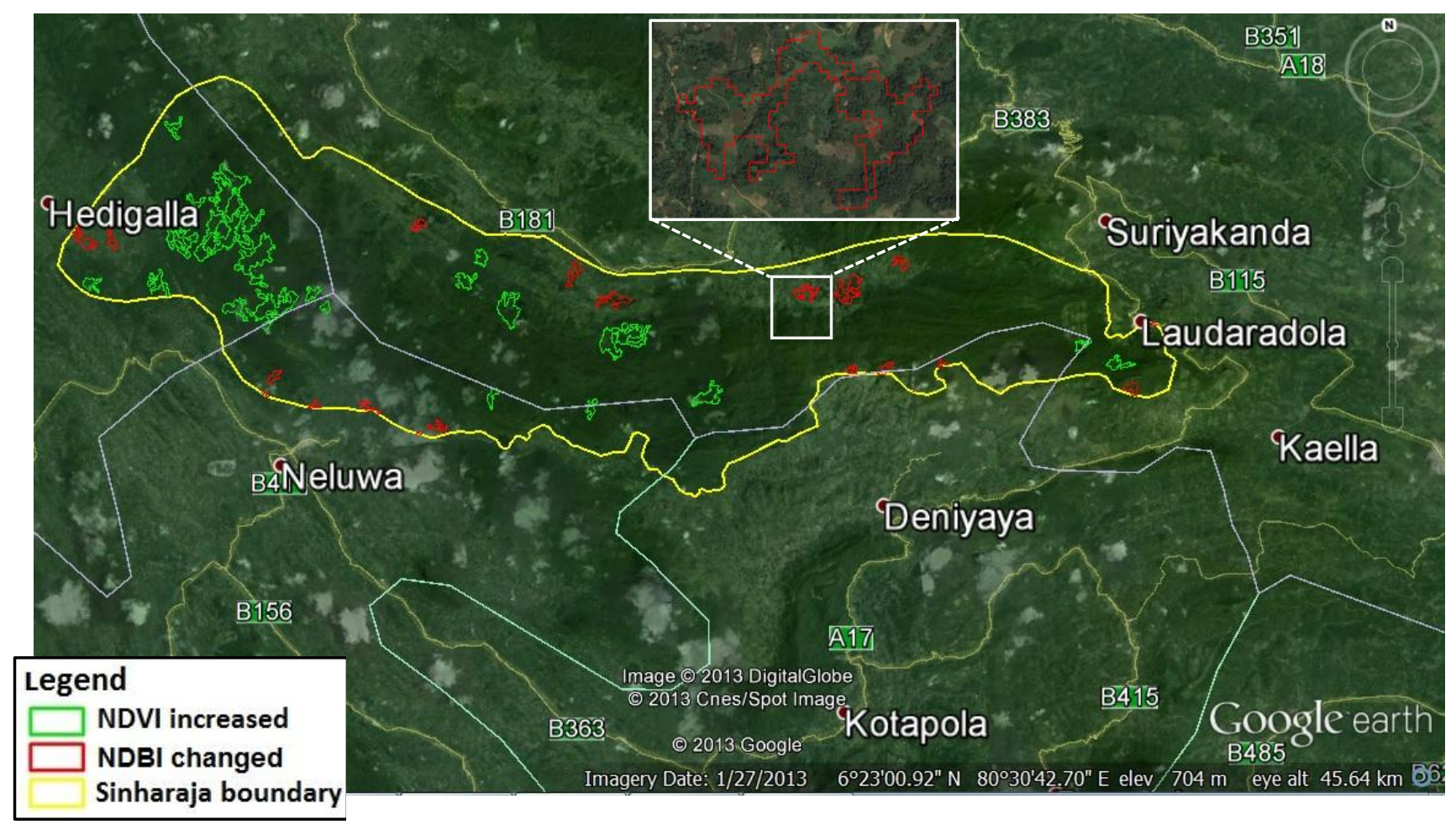

Fig. 3: Google earth view of the study area showing vegetation changed areas at the Sinharaja forest reserve fringe. The overview map zoomed into an area of NDVI decreased.

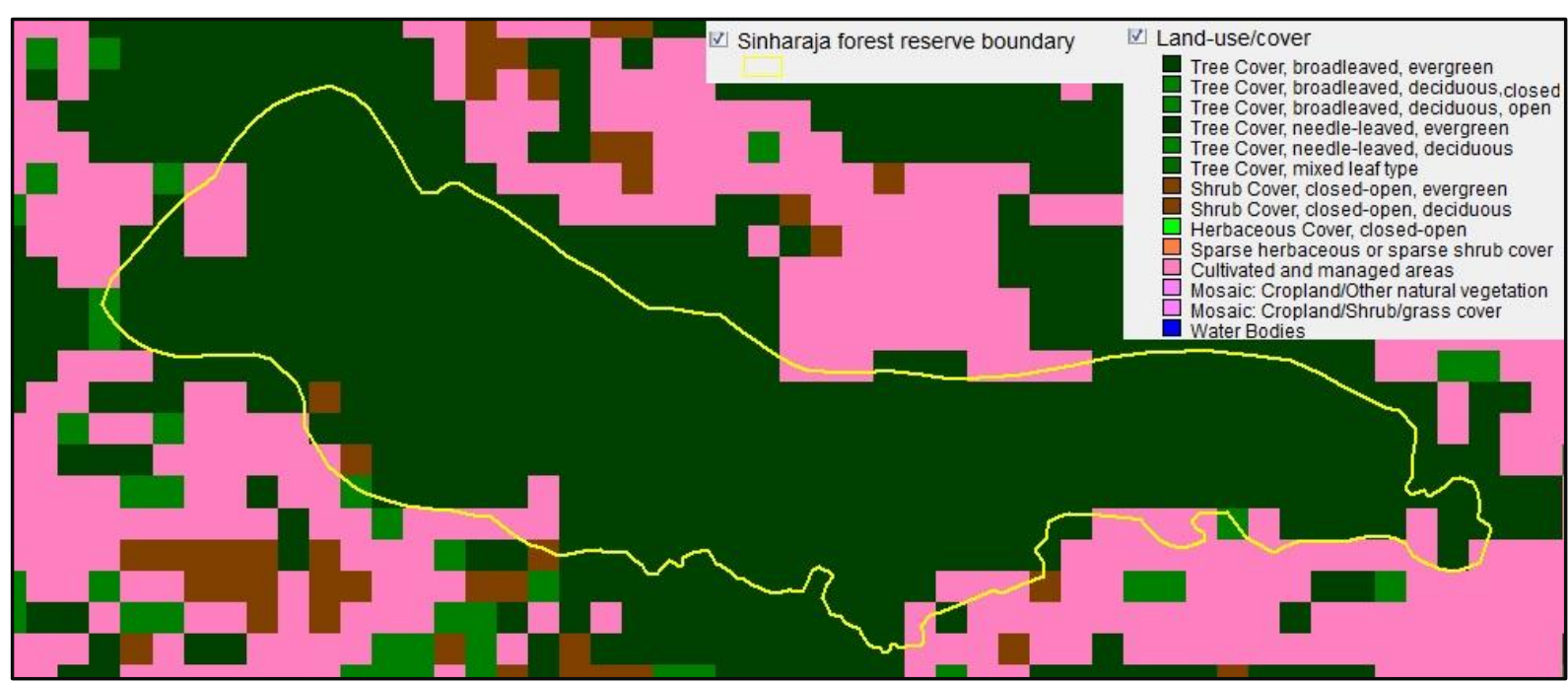

Fig. 4: Land-use/cover types at the Sinharaja forest reserve and suburbs. Land-use/cover data were acquired from DIVA GIS web portal. 
Table 3: Extent of land-use/cover within the Sinharaja reserve boundary.

\begin{tabular}{lrr}
\hline Landuse cover & Area, ha & Proportion, \% \\
\hline Tree cover, broadleaved, evergreen & 24,288 & 92.84 \\
Tree cover, broadleaved, deciduous, closed & 86 & 0.33 \\
Shrub-cover, closed-open, evergreen & 173 & 0.66 \\
Cultivated and managed & 1,615 & 6.17 \\
\hline
\end{tabular}

\section{Discussion}

This study shows how anthropogenic disturbances change vegetation in the Sinharaja MAB reserve, when an area is exposed to a historic fire scenario. Vegetation changes can be detected using NDVI, which reflects a habitat's health or a habitat's condition in given sites (Jayasuriya et al., 2009). For example, NDVI increase denotes vegetation growth such as canopy green-up, whereas NDVI decrease signifies forest fire or defoliation. According to our results on vegetation growth, or NDVI, increases can be conspicuous at the core region of the Sinharaja forest. The vegetation growth that clustered at the western Sinharaja could possibly be a result of secondary vegetation growth, resulting from selected logging during 1970's. Compared to old growth forest, this secondary forest could simulate leaf flushing on the canopy with a green-up. In contrast, NDVI decrease sites were in proximity to the burn sites, indicating that the slash and burn cultivation caused vegetation to decrease in Sinharaja. In addition, vegetation decrease areas in the Sinharaja buffer zone could be tea cultivated lands (Wijesooriya \& Gunatilleke, 2003). Similarly, Kanneliya forest reserve, which is a neighbouring forest to the Sinharaja forest reserve, experienced forest degradation due to tea cultivation resulting in scrublands (Lindström et al., 2012).

Habitat alterations resulting from adjacent land-use practices, in proximity to the Sinharaja forest boundary, grow towards the forest. For example, cropland and shrubland land-use types were observed within the forest reserve fringe (Fig. 5). This scenario leads to forest degradation such as: bottom-up effects (i.e. forest clearance for groundstory cardamom cultivation) and top-down effects (i.e. selective logging) (Ashton et al., 2001). Villages in proximity to the Sinharaja forest may demand forestlands for crop cultivation, resource extraction, forest clearance and cultivation (Surasinghe, 2004). Therefore, it is essential to introduce new land management policies to forest dwelling communities to conserve forest resources.

Pinus caribaea plantations were established between 1978 and 1982 at the abandoned shifting cultivation lands of the Sinharaja buffer zone (Shibayama et al., 2006) for forest gap management. Shibayama et al. (2006) suggested that groundstory fire at the Pinus caribaea plantations resulted in low diversity of trees and vines. Furthermore, they recommended groundstory fire protection for the $P$. caribaea plantation for best restoration management. In this study, we recommend to conduct a ground truthing survey for the burned areas in order to find the species compositional change resulting from historic fire scenario's. This would eventually provide valuable baseline information for the restoration of degraded lands in Sinharaja.

We found that six villages out of 41 villages are located at the fire-influenced sites within the $500 \mathrm{~m}$ buffer zone. Therefore, forest stewardship programs, in collaboration with local communities living at the disturbed forest areas, would eventually provide better forest conservation strategies. For example, it can introduce agroforestry systems to the villages, while introduce multipurpose tree species to enhance the livelihood of the local communities. 
Moreover, abandoned agricultural lands at the forest fringe can be managed, through the low cost-simple silvicultural method (Popham, 1993; Dilhan et al., 2010), to convert secondary forest. Then those rehabilitated forests fragments can be used to link with the existing natural forest through restoration corridors. Small-scale community based organizations are useful for making local communities aware of forest resources and restoration programs, and the communities can implement participatory forest management programs (Lindström et al., 2012).

The forest can be valuated by the ecosystem function of the tropical forests through carbon budgeting, and the Sinharaja MAB reserve may be ranked at the top for its carbon sequestration. The developed countries can make incentives to protect the natural forests, in terms of reducing GHG emissions that could be beneficial for local communities who are enrolling for the forest management programs. Concurrently, the Forest Department can initiate a spatial analyst project to identify and spatially display vulnerable forestlands in the Sinharaja to make decisions and plan support systems to implement new policies for conservation.

\section{References}

Ashton, M.S., Gunatilleke, C.V.S., Singhakumara, B.M.P., Gunatilleke, I.A.U.N., 2001. Restoration pathways for rain forest in southwest Sri Lanka: a review of concepts and models. Forest Ecology \& Management, 154:409-430.

Bandaratilleke, H.M., 1992. Managing the buffer zone in Sinharaja World Heritage Forest. PARKS, The International Magazine Dedicated to the Protected Areas of the World, 3:15-19.

de Zoysa, N.D., Gunatilleke, C.V.S., Gunatilleke, I.A.U.N., 1989. Secondary vegetation on an abandoned shifting cultivation site in the Sinharaja forest. The Sri Lanka Forester, 19:3-16.

de Zoysa, N., Raheem, R., 1990. Sinharaja, a rain forest in Sri Lanka, Colombo, Sri Lanka, March for Conservation.

Dilhan, M.A.A.B., Amarasinghe, J., Wijewardene, D.N.N., 2010. Building sustainable botanic gardens: a simple silvicultural method adopted to haven certain wood trees into productive arboretum in the dry zone of Sri Lanka, Proceedings of the Fourth Global Botanic Gardens Congress, Dublin, National Botanic Gardens of Ireland, pp.14.

Gunatilleke, C.V.S., Gunatilleke, I.A.U.N., 1985. Phytosociology of Sinharaja-A contribution to rain forest conservation in Sri Lanka. Biological Conservation, 31:21-40.

Gunatilleke, C.V.S., Gunatilleke, I.A.U.N., 1991. Threatened woody endemics of the wet lowlands of Sri Lanka and their conservation. Biological Conservation, 55:17-36.

Gunatilleke, C.V.S., Gunatilleke, I.A.U.N., 1996. Sinharaja: World Heritage Site, National Science Foundation, Colombo, Sri Lanka.

Gunatilleke, C.V.S., Gunatilleke, I.A.U.N., Abeygunawardena, P., 1993. Interdisciplinary research towards management of non-timber forest resources in lowland rain forests of Sri Lanka. Economic Botany, 47:282-290.

Gunatilleke, C.V.S., Perera, G.A.D., Ashton, P.M.S., Ashton, P.S., Gunatilleke, I.A.U.N., 1996. Seedling growth of Shorea section Doona (Dipterocarpaceae) in soils from topographically different sites of Sinharaja rain forest in Sri Lanka, in: Swaine, M.D., (Ed.), Man and the Biosphere Series, UNESCO, Paris, Parthenon Publishing, Carnforth, UK, pp 245-263. 
Gunatilleke, I.A.U.N., Gunatilleke, C.V.S., Dilhan, M.A.A.B., 2005. Plant biogeography and conservation of the south-western hill forests of Sri Lanka. The Raffles Bulletin of Zoology, 12:9-12.

Gunatilleke, H.M., 1998. The role of rural development in protecting tropical rainforests: evidence from Sri Lanka. Journal of Environmental Management, 53:273-292.

Jayasuriya, A.H.M., Kitchener, D.J., Biradar, C.M., 2009. Variability status of biosphere reserves in Sri Lanka. Journal of National Science Foundation Sri Lanka, 37:7-24.

Jensen, J. 2005. Remote sensing of the environment: an earth resource perspective. $2^{\text {nd }}$ ed. Pearson Education Inc.

Kathriarachchi, H.S., Tennakoon, K.U., Gunatilleke, C.V.S., Gunatilleke, I.A.U.N., Ashton, P.M.S., 2004. Ecology of Two Selected Liana Species of Utility Value in a Lowland Rain Forest of Sri Lanka: Implications for Management. Conservation and Society, 2:273-288.

Key, C.H., Zhu, Z., Ohlen, D., Howard, S., McKinley, R., Benson, N., 2002. The normalized burn ratio and relationships to burn severity: ecology, remote sensing and implementation, in: Greer, J.D. (Ed.), Rapid Delivery of Remote Sensing Products. Proceedings of the Ninth Forest Service Remote Sensing Applications Conference, San Diego, American Society for Photogrammetry and Remote Sensing, Bethesda, MD.

Lindström, S., Mattsson, E., Nissanka, S.P., 2012. Forest cover change in Sri Lanka: The role of small scale farmers. Applied Geography, 34:680-692.

McDermott, M., Gunatilleke, C.V.S., Gunatilleke, I.A.U.N., 1990. The Sinharaja rain forest: conserving both biological diversity and a way of life. The Sri Lanka Forester, 19:322.

National Conservation Review [NCR]. 1997. Designing an optimum protected areas system for Sri Lanka's natural forests, Vol. 1. IUCN/FAO.

Popham, F. H., 1993. Dambulla. A Sanctuary of tropical trees. Sam Popham foundation, UK.

Prakasam C. 2010. Land use and land cover change detection through remote sensing approach: A case study of Kodaikanaltaluk, Tamilnadu. International Journal of Geo matics and Geosciences, 1:150-158.

Shibayama, T., Ashton, M.S., Singhakumara, B., Griscorm, H.P., Ediriweera, S., Griscom, B.W., 2006. Effects of fire on the recruitment of rain forest vegetation beneath Pinus caribaea plantations, Sri Lanka. Forest Ecology \&d Management, 226:357-363.

Sri Bharathie, K.P., 1979. Natural regeneration in the exploited section of the Sinharaja Reserve. The Sri Lanka Forester, 14:41-42.

Surasinghe, T.D., 2004. Distribution and habitat selection of agamid lizards in the Sinharaja Man and Biosphere Reserve, B.Sc. Dissertation, University of Colombo, Sri Lanka.

Wijesooriya, W.A.D.A., Gunatilleke, C.V.S., 2003. Buffer zone of the Sinharaja biosphere reserve in Sri Lanka and its management strategies. Journal of National Science Foundation Sri Lanka, 31:57-71. 